\section{Mentoring Interventions for Underrepresented Scholars in Biomedical and Behavioral Sciences: Effects on Quality of Mentoring Interactions and Discussions}

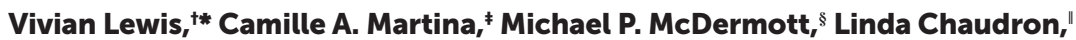 \\ Paula M. Trief, \\ Gene D. Morse, ${ }^{t+}$ and Richard M. Ryan ${ }^{\neq \ddagger}$ \\ ${ }^{\dagger}$ Department of Obstetrics and Gynecology, "Department of Public Health Sciences, sDepartments \\ of Biostatistics and Computational Biology and Neurology, and "Department of Psychiatry, \\ University of Rochester School of Medicine and Dentistry, Rochester, NY 14642; "Departments of \\ Psychiatry and Behavioral Sciences and Medicine, State University of New York Upstate Medical \\ University, Syracuse, NY 13210; \#Counseling \& Psychological Services, University of California, \\ Santa Barbara, Santa Barbara, CA 93106; ${ }^{\circledR}$ University of Rochester School of Nursing, Rochester \\ NY 14642; ** Departments of Pediatrics and Physiology, University of Tennessee Health Science \\ Center, Memphis, TN 38163; "ISchool of Pharmacy and Pharmaceutical Sciences, University at

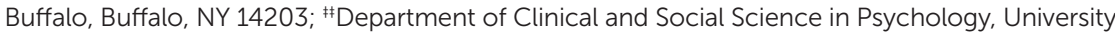 \\ of Rochester, Rochester, NY 14627
}

\begin{abstract}
Mentors rarely receive education about the unique needs of underrepresented scholars in the biomedical and behavioral sciences. We hypothesized that mentor-training and peer-mentoring interventions for these scholars would enrich the perceived quality and breadth of discussions between mentor-protégé dyads (i.e., mentor-protégé pairs). Our multicenter, randomized study of 150 underrepresented scholar-mentor dyads compared: 1) mentor training, 2) protégé peer mentoring, 3) combined mentor training and peer mentoring, and 4) a control condition (i.e., usual practice of mentoring). In this secondary analysis, the outcome variables were quality of dyad time and breadth of their discussions. Protégé participants were graduate students, fellows, and junior faculty in behavioral and biomedical research and healthcare. Dyads with mentor training were more likely than those without mentor training to have discussed teaching and work-life balance. Dyads with peer mentoring were more likely than those without peer mentoring to have discussed clinical care and career plans. The combined intervention dyads were more likely than controls to perceive that the quality of their time together was good/excellent. Our study supports the value of these mentoring interventions to enhance the breadth of dyad discussions and quality of time together, both important components of a good mentoring relationship.
\end{abstract}

\section{INTRODUCTION}

Mentors help their protégés to acquire the knowledge, skills, and competencies needed for success in academia. This support is of particular importance to women and underrepresented minorities in biomedical, health science, and behavioral science disciplines at all stages of their careers. Mentors facilitate acculturation into a discipline in a process that typically involves helping a protégé to develop a professional identity and network (Kram and Ragins, 2007; Faupel-Badger et al., 2015). For underrepresented groups, acculturation is often complicated by disparate cultural
Jose Herrera, Monitoring Editor

Submitted July 10, 2016; Revised March 29, 2017; Accepted April 13, 2017

CBE Life Sci Educ September 1, 2017 16:ar44 DOI:10.1187/cbe.16-07-0215

*Address correspondence to: Vivian Lewis (vivian .lewis(arochester.edu).

() 2017 V. Lewis et al. CBE-Life Sciences

Education @ 2017 The American Society for Cell Biology. This article is distributed by The American Society for Cell Biology under license from the author(s). It is available to the public under an Attribution-Noncommercial-Share Alike 3.0 Unported Creative Commons License (http://creativecommons.org/licenses/ by-nc-sa/3.0).

"ASCB®" and "The American Society for Cell Biology ${ }^{\circledR}$ " are registered trademarks of The American Society for Cell Biology. 
(Gonzales-Figueroa and Young, 2005) and societal expectations, bias (Carr et al., 2003; Carnes et al., 2015), prejudice (Price et al., 2009), and social and professional isolation (Pololi et al., 2010; Kaatz and Carnes, 2014), as well as lack of self-confidence (Isaac et al., 2012). Despite good intentions, mentors can be ill-equipped to address these needs (Fleming et al., 2013). They may lack formal mentoring training (Silet et al., 2010), exposure to diverse populations, or awareness of their own privilege (Sue, 2011), and their institutions may provide inadequate support (Sue, 2008; Stewart et al., 2012). Only a handful of studies have offered empirical evidence about ways that mentors might acquire or improve their skills to support their protégés (Johnson et al., 2010; Feldman et al., 2012; Pfund et al., 2014), and most of these studies focus on traditional one-on-one mentoring, often aimed at a single career stage. To date, few reported studies have focused specifically on mentoring of graduate and postdoctoral students and faculty from underrepresented populations.

Recent studies have suggested the value of alternatives to the traditional one-on-one mentoring model. In a study of National Institutes of Health (NIH) K grant awardees, DeCastro et al. (2013) stressed the benefits of both traditional mentoring and horizontal mentorship by peers. Horizontal mentorship can facilitate academic and professional development through mutual support, shared learning, collaboration, and flexibility-benefits that appear to be particularly important to junior faculty women (Johnson et al., 2011; DeCastro et al., 2013). Similarly, Pololi et al. (2002) described a collaborative peer-mentoring program for junior faculty that helped participants identify their core values and career goals. Participants experienced improved job satisfaction that was linked to plans to remain in academic medicine (Pololi et al., 2002; Pololi and Knight, 2005). Peer mentoring may be particularly critical for women and underrepresented minorities, as it may counteract feelings of isolation and marginalization (Turner et al., 2008; Pololi et al., 2010). These reports stress the importance of skilled mentoring and peer networks in meeting both the psychosocial and academic needs of protégés. However, little, if any, empirical evidence indicates which types of mentoring or approaches to mentor training are likely to be successful.

Our study of traditional and peer-mentoring interventions is supported by self-determination theory (SDT) (Ryan and Deci, 2000) and social capital theory (Bourdieu, 1986). SDT is an empirically based meta-theory of motivation that argues that individuals are most productive when their basic psychological needs for competence, autonomy, and relatedness are met. Evidence from healthcare, business, and education shows that teachers, supervisors, and settings that address these basic psychological needs promote workplace satisfaction, persistence, and productivity (Ryan and Deci, 2000; Baard et al., 2004; Millette and Gagné, 2008; Lewis et al., 2016). SDT directed the design of our mentor training. Social capital theory, which was the basis for the peer-mentoring intervention, stresses the importance of social networks in helping individuals acquire institutional knowledge and understanding of the culture by which academia operates. Through peer network associations, underrepresented groups can combat feelings of isolation and marginalization, which can reduce attrition from academia among women and minorities (Pololi et al., 2002, 2013; Pololi and Knight, 2005). In a study of underrepresented minority faculty in academic medical centers, Cora-Bramble found that both having the right mentor and developing a supportive network were associated with resilience and academic productivity, as measured by publications and grants (Cora-Bramble et al., 2010). Hence, in combination, SDT and social capital theory offer compatible approaches to addressing the mentoring needs of women and underrepresented minority scholars.

For this substudy, we conducted secondary analyses of data from a randomized, controlled trial that compared 1) mentor training based on SDT, 2) peer mentoring based on social capital theory, 3) combined mentor-training and peer-mentoring interventions, and 4) a control condition (usual practice of mentoring; Lewis et al., 2016). We examined the effects of these mentoring interventions on mentor-protégé discussions of topic areas that are important for academic success of scholars at multiple career stages (Martina et al., 2014). We hypothesized that mentoring interventions for underrepresented scholars would enrich both the perceived quality and the perceived breadth of discussions between mentor-protégé dyads (i.e., mentor-protégé pairs). We evaluated 1) differences between mentors' and protégés' perceptions about the quality of their time together; 2) associations between race, ethnicity, and gender and mentor-protégé perceptions of the quality of their time together; and 3) the effects of the interventions on mentor-protégé discussions of specific topics.

Our group of scholars included graduate students, fellows, and junior faculty to ensure that we could study mentoring interventions that were applicable to underrepresented groups at a range of career stages. Several authors have argued for the need to address diversity (including racial, ethnic, and gender diversity) in designing mentor competencies or in mentor training, because perceptions about mentoring often differ by race, ethnicity, or gender (Abedin et al., 2012; Pfund et al., 2013; Prunuske et al., 2013). Therefore, we evaluated the associations between these demographic characteristics and the perceived amount and quality of time spent with the mentor. We assessed mentor-protégé agreement with respect to perceived amount and quality of time spent together, as well as whether specific topics were discussed during their encounters, because clear communication is critical for aligning expectations and accomplishing academic goals (Huskins et al., 2011; Abedin et al., 2012; Pfund et al., 2013). We focused on the dyad time together as an indicator of quality of the mentoring relationship as perceived by both the mentor and protégé. We asked whether the amount of time together was perceived to be adequate, because having access to one's mentor is a critical aspect of a successful mentoring relationship, while lack of time is a barrier commonly cited by both mentors and protégés (Johnson, 2007; Johnson et al., 2010). In addition, quality of time together is critical to the success of any mentoring relationship.

\section{METHODS \\ Participants and Setting for the Randomized Controlled Trial}

We recruited mentor-protégé dyads from 11 research sites (three academic medical centers and eight universities/colleges) in western New York State (see Acknowledgments). Protégés were all from health sciences or related biomedical fields. All protégés were graduate students, fellows, or junior faculty who were underrepresented in their disciplines on the 
basis of at least one of the following characteristics: self-described race (e.g., African-American or Black individuals, Native Americans and Pacific Islanders), ethnicity (Latinos or Hispanics), gender (women in biomedical research or healthcare, men in nursing), or socioeconomic status (considered only for graduate students in our sample). Being a first-generation college graduate was used as a proxy measure for socioeconomic status. The study intentionally included a broad sample of protégés from different institutions, different disciplines of science and medicine, and different career stages who were united in their underrepresented status within their disciplines, as many principles of mentoring and issues confronting underrepresented scholars are shared. Every protégé was required to have a mentor upon entering the study.

After completing a Web-based screening questionnaire for eligibility, protégés and mentors who met enrollment criteria were contacted and scheduled separately to complete the informed-consent process. The study coordinator then randomly assigned each mentor-protégé dyad to one of four groups, as described above and previously (Lewis et al., 2016). Dyads were recruited in three cohort samples, each of which participated in the study for 1 year.

This study was approved by the following institutional review boards: University of Rochester (study RSRB0003374), State University of New York (SUNY) Upstate Medical University (IRBPHS\#600), University at Buffalo Health Sciences Institutional Review Board (HSIRB\#PHP1111210E), Roswell Park Cancer Institute Scientific Review Committee (\#196611), Rochester Institute of Technology (no number available), College at Brockport (\#2011-72), and SUNY Geneseo (project \#201112002).

\section{Study Design and Time Frame}

For the substudy described in this report, we used data collected at baseline and at the end of 12 months. We compared four groups: 1) mentor training, 2) peer mentoring, 3) combined, and 4) control condition (usual practice of mentoring). Regardless of group assignment, all mentor-protégé dyads continued to meet throughout the year. Interactions within these dyads were the focus of this substudy.

\section{Brief Description of Mentoring Interventions}

Mentor Training. This intervention targeted mentors only, and included an introductory workshop and field exercises to apply and reinforce learning about the SDT-based model of mentor training, CARES: competence, autonomy, relatedness, equity, and structure. Mentors attended a 2-hour workshop to learn the importance of protégé competence, autonomy, and relatedness, as well as what SDT considers to be facilitators of these needs, namely equity (basic fairness, compensation, resources) and structure (formal set of rules that govern the academic workplace) (Deci and Ryan, 2014). Competence refers to feeling confident in one's ability (including having the requisite knowledge and skills) to accomplish a specific goal. Autonomy refers to a sense of volition with respect to goal choice, and methods by which one reaches goals, along with a personal commitment to goal achievement. Relatedness is the need for feeling attached and connected to important others and valued implicitly by others in one's social world (Deci and Ryan, 2000). When mentors support these needs, their protégés are likely to experience more autonomous motivation for achieving self-determined goals (Deci et al., 2017). During the workshop, facilitators guided mentors to reflect upon and discuss the importance of each of these principles in their own professional and personal development through a series of experiential exercises. Mentors were given references to read and a set of questions specific to each SDT principle to guide a discussion with their protégés. Mentors were asked to then interview their protégés to understand their protégés' perspectives within each of these domains. We explicitly instructed mentors that 1 ) the interview was designed to be a listening exercise to understand what life was like for their protégés, and 2) the interview should not include evaluation or problem solving. Following these protégé interviews, study staff conducted 1-hour individual interviews with mentors to explore what they had learned from their protégés and how the interviews progressed.

The questions the mentors were expected to ask the protégés covered each element of the CARES model and allowed the protégés to self-assess their experiences with their mentor. The four questions about Competence included areas of both proficiency and availability of guidance and feedback to promote mastery. Five questions about Autonomy asked about the personal interests and goals that were most important to the protégé, and provisions of support versus pressure to focus on these aims. Six questions about Relatedness included perceptions of being welcome and valued by others and an invitation for feedback about the relationship with their mentor. The seven Equity questions explored perceived fairness overall and availability of tangible resources for the protégé (e.g., compensation, space, training, time). Questions about Structure dealt with clarity of rules and expectations around advancement and feedback. By encouraging dialogue about the protégés' experiences in the areas of both professional development and psychosocial needs, we predicted that the SDT-based mentor training would be associated with discussion of a greater breadth of topics and perceived higher quality of time together.

We expected that protégés whose mentors were successful in supporting both their professional and psychosocial needs would perceive a higher quality of time with their mentors. Because protégés would theoretically feel free to talk about issues of importance to them, the dyad would engage in discussions about a range of topics that included academic skills and professional and personal development. Thus, we hypothesized that supporting these mentoring needs of the protégés would be associated with higher perceived quality of time together and greater breadth of topics discussed over the course of a year.

Peer Mentoring. This intervention targeted the protégés only and it was based on social capital theory. Peers can provide social networks that facilitate the sharing of both informal (implicit) and formal (explicit) knowledge about academic and institutional culture and professional identity in a supportive environment (Lin, 1999a,b). For many minorities and women, the culture of academia may seem fraught with invisible hierarchical systems that prevent career advancements and rewards (Bourdieu and Wacquant, 1992). Academic peers can offer horizontal connections: they have real-time, insider knowledge of navigating an unfamiliar and sometimes intimidating landscape of academia. Understanding who gets what and how they 
get it is often obscure. This peer-networking process promotes change through ongoing discussion and debate and is strengthened through shared knowledge (Bourdieu, 1998). These network associations also combat feelings of isolation and marginalization and can therefore reduce attrition from academia among women and minorities (Pololi et al., 2002, 2013; Pololi and Knight, 2005). In addition, protégés in peer groups will likely benefit from knowledge acquired from their peers that can enable them to decode the often obscure implicit knowledge of institutional academic culture. Thus, peer mentoring could also support feelings of relatedness: peers' shared experiences in a nonthreatening environment can facilitate connectedness in academia and strengthen the mentor-protégé relationship. In sum, peer-mentoring support was expected to enhance perceptions of self-worth/autonomy and the mentorprotégé relationship.

We created peer groups of three to six protégés within each yearly cohort, based on protégé preferences (discipline, race, gender, ethnicity, location). All groups met for the year of their involvement in the study. Each small group was composed of individuals at similar stages in their careers. We provided a 3-hour formal workshop for each cohort at the beginning of the intervention for all of the small groups together. The first workshop included general information about peer mentoring, structure and format of typical peer meetings, and examples of successful peer-mentoring group outcomes to illustrate the power of social networks in facilitating professional and academic success. We also discussed the importance and use of individual career plans, and how to optimize mentor-protégé relationships to achieve goals.

Each peer group then met independently, usually once or twice per month for the year. They set their own agendas for these meetings. We provided at least three additional formal workshops each year for the entire cohort. The topics for these workshops were chosen based on the peer-mentoring protégé responses to email evaluation surveys sent as part of follow-up after each cohort session. We facilitated these workshops, often including guest faculty with expertise in the subject matter chosen.

Overall, peer-mentor support could facilitate protégé-mentor discussions of both academic issues and personal topics such as work-life balance and social and professional isolation and exclusion. With this enhanced relationship, we hypothesized that dyads in the peer-mentoring groups would perceive higher quality of time together and discuss a greater breadth of topics over the course of a year.

Combined. This intervention provided both the mentor training for mentors and the peer mentoring for the protégés. We sought to determine whether both approaches combined would provide enhanced effects on perceptions of dyad quality of time and range of topics discussed.

Control (Usual Practice of Mentoring). Mentors and protégés continued to work together throughout the year, but no intervention was provided for either mentors or protégés.

\section{Questionnaire and Data Collection}

We used a previously developed instrument to measure the impact of the total mentor/protégé experience that has been shown to be reliable and consistent when used with a similar population (Martina et al., 2014). This tool was adapted from a questionnaire used since 2007 by the University of Rochester Clinical and Translational Science Institute (CTSI) to help evaluate mentoring of early-career scholars. The instrument was developed for use with mentors and protégés from a broad array of scientific disciplines. The protégés in the Rochester CTSI are graduate students, fellows, and junior faculty whose responsibilities vary, like those of our study population. Peer review of the instrument over three NIH grant-funding cycles, by both external and internal evaluators, has supported its usefulness.

The questionnaire was consistent with both SDT principles and social capital theory, in that it assessed the quality of dyad time together and the quality of their mentoring interactions. Also, consistent with social capital theory, the tool assessed the attainment of the types of knowledge important for understanding how the system of academia works in acquiring social capital within academic institutions.

Mentors and protégés completed parallel questionnaires at baseline and 1 year later. The tool measured overall satisfaction with the adequacy of the total amount of time spent as a dyad and included a separate question on the quality of time spent as a dyad (both rated as poor, fair, good, or excellent). It also asked participants to indicate whether they had discussions as a mentor-protégé dyad in one or more of the following seven topic domains: 1) teaching, 2) research, 3) clinical care, 4) presentation skills, 5) networking, 6) career planning, and 7) work-life balance. The questionnaire allowed respondents to select multiple topics of discussion. Because mentor-protégé dyads in this study represented a variety of career paths (clinician, educator, scientist), disciplines (healthcare, science, technology, engineering, and mathematics, etc.), and training levels (graduate student, postdoctoral fellow, early-career faculty), respondents were given the opportunity to indicate yes, no, or not applicable for dyad discussion of each of the seven domains.

\section{Statistical Analysis}

Before doing the data analysis, we dichotomized the outcomes of total amount of time spent together and quality of time spent as good/excellent versus poor/fair. The rationale for dichotomization was that it avoided sparse cells for several responses, and it provided a natural division of responses into "satisfactory" versus "not satisfactory" categories, thus greatly simplifying the presentation of results.

We then performed logistic regression analyses to compare intervention groups at month 12 . The model included both protégé and mentor responses and was fitted using generalized estimating equations (Diggle et al., 2002) to account for the association between the mentor and protégé responses in the same dyad. We used the technique of alternating logistic regressions with the associations between outcomes within the same dyad, which was modeled using a constant log odds ratio (Carey et al., 1993). The model included terms for intervention group, respondent (mentor, protégé), and response to the item at baseline. We used this model to examine intervention effects in dyads as a whole and to compare mentors and protégés regarding responses to questionnaire items. We included the interaction between intervention group and respondent in a model that examined intervention effects separately in mentors and protégés. 
We used similar logistic regression models, adding gender or race/ethnicity and the interaction between respondent and gender (or race/ethnicity), to examine differences by gender and by race/ethnicity.

\section{RESULTS}

\section{Sample}

We enrolled 150 protégé-mentor dyads between 2010 and 2013. All protégés were underrepresented in their fields based on at least one characteristic (race, ethnicity, gender, disability, or socioeconomic status). The protégé group was $83 \%$ female, whereas the mentor group was $47 \%$ female. There were more racial and ethnic minorities in the protégé group than the mentor group. Among the protégés, 13\% were Hispanic/Latino/a compared with $5 \%$ of the mentors. Racial minorities and individuals of more than one race or unknown race made up $47 \%$ of the protégés, compared with only $9 \%$ of mentors. The proportion of first-generation college graduates was similar among protégés and mentors (35\% and 37\%, respectively). No important differences were found between the four groups with respect to the distribution of scientific fields, gender, ethnicity, race, or first-generation college graduation status (Table 1).

Among protégés, 48\% were junior faculty, 42\% graduate students, and $10 \%$ postdoctoral fellows. Among all randomized dyads, $87 \%$ completed the final questionnaire. No significant differences in attrition rates were found across the four conditions. Completion rates for the three intervention groups ranged from $82.1 \%$ for the peer-mentoring group to $89.2 \%$ for the mentor-training group; the rate was $94 \%$ for the control group. As previously reported, the reasons for attrition were: relocation (six participants), time conflicts (five participants), loss to follow up (five participants), and withdrawal of consent (two participants) (Lewis et al., 2016).

\section{Perceptions of Mentor-Protégé Dyads across All Intervention Groups}

By month 12, the topics reported to be most commonly discussed by dyads across all groups were research and career planning; the least discussed was clinical care. Mentors and protégés varied in their perception of whether a specific topic had been discussed (Figure 1). After correction for baseline responses, we found that mentors were significantly more likely than protégés to report discussions of teaching (odds ratio [OR] $=1.79 ; 95 \%$ confidence interval $[\mathrm{CI}]=1.07-3.00 ; p=0.03$ ), networking $(\mathrm{OR}=2.68 ; 95 \% \mathrm{CI}=1.59-4.53 ; p=0.0002)$, career planning (OR 2.66; 95\% CI $=1.40-5.06 ; p=0.003$ ), and work-life balance (OR $=2.26$; 95\% CI $=1.41-3.63 ; p=0.0008)$. Furthermore, mentors were more likely than protégés to assess the amount of their time together as adequate $(\mathrm{OR}=2.02 ; 95 \%$ $\mathrm{CI}=1.24-3.28, p=0.005)$. In contrast, mentors and protégés did not differ significantly with respect to their likelihood of rating the quality of their time together as good or excellent.

We next looked across all intervention groups for associations between race/ethnicity of the protégés and overall time together and range of topics discussed (Table 2). Mentors of Black or Hispanic protégés were less likely than mentors of

TABLE 1. Characteristics of protégés at baseline in a multicenter, randomized controlled trial of mentoring interventions, 2010-2013

\begin{tabular}{|c|c|c|c|c|c|}
\hline Characteristic & $\begin{array}{c}\text { Mentor training } \\
n(\%)\end{array}$ & $\begin{array}{c}\text { Peer mentoring } \\
n(\%)\end{array}$ & $\begin{array}{c}\text { Combined } \\
n(\%)\end{array}$ & $\begin{array}{c}\text { Control condition } \\
n(\%)\end{array}$ & $\begin{array}{l}\text { All groups } \\
n(\%)\end{array}$ \\
\hline \multicolumn{6}{|l|}{ Gender } \\
\hline Male & $6(16)$ & $5(13)$ & $9(24)$ & $6(16)$ & $26(17)$ \\
\hline Female & $31(84)$ & $34(87)$ & $28(76)$ & $31(84)$ & $124(83)$ \\
\hline \multicolumn{6}{|l|}{ Ethnic category } \\
\hline Hispanic or Latino & 5 (14) & $5(13)$ & $4(11)$ & $6(16)$ & 20 (13) \\
\hline Not Hispanic or Latino & $32(86)$ & $34(87)$ & $33(89)$ & $31(84)$ & $130(87)$ \\
\hline \multicolumn{6}{|l|}{ Racial category } \\
\hline Asian & $4(11)$ & $7(18)$ & $4(11)$ & $4(11)$ & $19(13)$ \\
\hline Black/African American & 7 (19) & $10(26)$ & $9(24)$ & $10(27)$ & $36(24)$ \\
\hline Pacific Islander & $0(0)$ & $1(3)$ & $0(0)$ & $0(0)$ & $1(1)$ \\
\hline White & $22(59)$ & $18(46)$ & $22(59)$ & $18(49)$ & $80(53)$ \\
\hline Unknown/other/more than one race & $4(11)$ & $3(8)$ & $2(5)$ & $5(14)$ & $14(9)$ \\
\hline \multicolumn{6}{|l|}{ Other characteristics } \\
\hline Disability & $3(8)$ & $4(10)$ & $2(5)$ & $1(3)$ & $10(7)$ \\
\hline First-generation college graduate & $13(35)$ & $15(38)$ & $14(38)$ & $9(24)$ & $51(35)$ \\
\hline \multicolumn{6}{|l|}{ Scientific field } \\
\hline Health professions & $18(49)$ & $18(46)$ & $19(51)$ & $19(51)$ & 74 (49) \\
\hline Life sciences & $8(22)$ & $8(20)$ & $5(14)$ & $5(14)$ & $26(17)$ \\
\hline Behavioral and social sciences & 7 (19) & $7(18)$ & $8(22)$ & $9(24)$ & $31(21)$ \\
\hline Engineering and physical sciences & $4(11)$ & $6(15)$ & $5(14)$ & $4(11)$ & $19(13)$ \\
\hline \multicolumn{6}{|l|}{ Career stage } \\
\hline Graduate student & $20(54)$ & $13(33)$ & $12(32)$ & $18(49)$ & $63(42)$ \\
\hline Fellow & $1(3)$ & $5(13)$ & $5(14)$ & $4(11)$ & $15(10)$ \\
\hline Faculty member & $16(43)$ & $21(54)$ & $20(54)$ & $15(40)$ & $72(48)$ \\
\hline
\end{tabular}




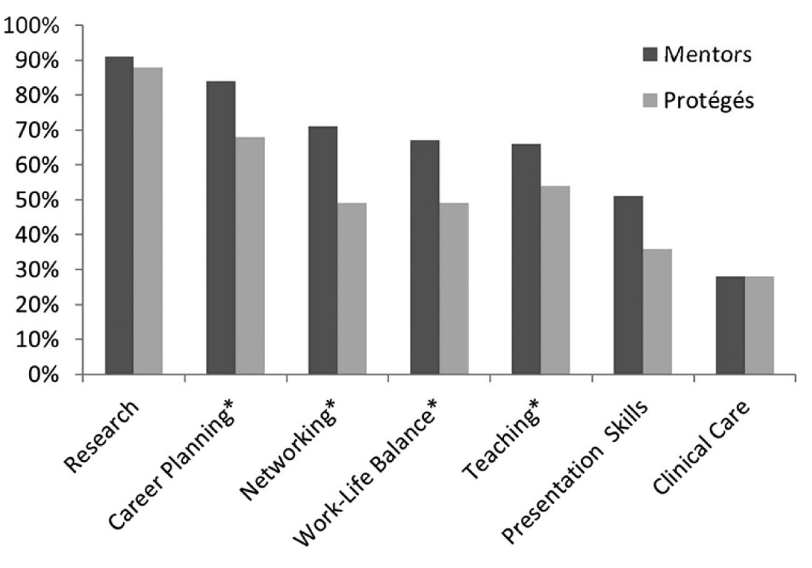

FIGURE 1. Comparison of reported topics of discussion between mentors and protégés at 12 months in terms of the percentages of mentors and protégés who indicated that they discussed a given topic as a dyad. The results reported here are for mentors and protégés from all four randomized groups combined. Note that respondents were able to check as many topics as they liked. Asterisks denote $p$ values of $<0.05$ in comparing mentors and protégés.

white protégés to perceive that the amount of time spent with their protégés was adequate $(\mathrm{OR}=0.33 ; 95 \% \mathrm{CI}=0.13-0.82$; $p=0.02$ ). In contrast, Black and Hispanic protégés themselves appeared to be more likely than white protégés to consider that the time spent with their mentors was adequate, though the odds ratio was not significant $(\mathrm{OR}=2.22 ; 95 \% \mathrm{CI}=0.84-5.89$; $p=0.11$ ). Comparing dyads with racial/ethnic minority protégés with those with white protégés, we found no significant differences in the topics discussed.

No significant difference was found by protégé gender in the odds of rating total amount or quality of time together as good or excellent (Table 2). However, dyads with female protégés, compared with dyads with male protégés, were more likely to report discussing clinical care $(\mathrm{OR}=6.22$; 95\% CI $=1.45$ $26.80 ; p=0.01)$ and work-life balance $(\mathrm{OR}=2.25 ; 95 \% \mathrm{CI}=$ $0.99-5.12 ; p=0.05)$.

\section{Effects of Interventions on Time Spent and Topics Discussed}

The quality of time together was significantly more likely to be rated good/excellent by dyads in the combined intervention group compared with those in the control group (OR $=4.24$; $95 \% \mathrm{CI}=1.26-14.30 ; p=0.02$ ). Dyads assigned to peer mentoring, compared with other dyads, showed a trend toward higher ratings of the quality of time together $(\mathrm{OR}=2.12 ; 95 \% \mathrm{CI}=$ $1.00-4.48, p=0.05$; Table 3 ). Intervention dyads were no more likely than control dyads to describe the amount of time together as adequate. However, when considering mentor and protégé responses separately, mentors in the mentor-training group and mentors with protégés in the peer-mentoring group were more likely than the control group mentors to perceive that the total amount of time together was adequate (mentor training vs. control: $\mathrm{OR}=3.02 ; 95 \% \mathrm{CI}=1.04-8.82 ; p=0.04$; peer mentoring vs. control: $\mathrm{OR}=3.46 ; 95 \% \mathrm{CI}=1.01-11.83$; $p=0.05)$.

The effects of the interventions on the odds of reporting discussions of various topics are shown in Table 4. Mentor-training dyads were more likely to discuss both teaching and work-life balance than dyads with no mentor training. When compared with the control group, work-life balance discussions were more likely to be reported in the mentor-training dyads (OR = $2.51 ; 95 \% \mathrm{CI}=1.09-5.77 ; p=0.03$ ) and in the dyads with both mentor training and peer mentoring $(\mathrm{OR}=5.02 ; 95 \% \mathrm{CI}=$ 2.09-12.07; $p=0.0003$ ). Discussions of both clinical care and career planning were more likely to be reported in peer-mentoring dyads than in those without peer mentoring. We found no significant effect of peer mentoring, compared with the control condition, on topics discussed.

\section{DISCUSSION}

In a sample of scholars who were underrepresented in their disciplines based on race, ethnicity, gender, disability, or socioeconomic status, we found that mentors and protégés had differing perceptions of their time together and of which topics were discussed during their conversations. Overall, few differences were found in perceptions of time spent together based on the gender, race, or ethnicity of the protégé. We found that while the

TABLE 2. Associations between protégé gender, race, and ethnicity and perceived amount and quality of time spent with mentor ${ }^{a}$

\begin{tabular}{|c|c|c|c|c|}
\hline \multirow[b]{2}{*}{ Comparison $^{\mathrm{b}}$} & \multicolumn{2}{|c|}{$\begin{array}{c}\text { Total amount of time is } \\
\text { adequate }^{\mathrm{c}}\end{array}$} & \multicolumn{2}{|c|}{$\begin{array}{l}\text { Quality of time is good/ } \\
\text { excellent }^{c}\end{array}$} \\
\hline & OR $(95 \% \mathrm{CI})$ & $p$ value & OR $(95 \% \mathrm{CI})$ & $p$ value \\
\hline Black/Hispanic protégés compared with white protégés & $2.22(0.84-5.89)$ & 0.11 & $1.37(0.51-3.67)$ & 0.54 \\
\hline Mentors of Black/Hispanic protégés compared with mentors of white protégés & $0.33(0.13-0.82)$ & 0.02 & $0.49(0.15-1.59)$ & 0.24 \\
\hline White protégés compared with Asian protégés & $0.74(0.28-1.98)$ & 0.55 & $0.35(0.06-1.99)$ & 0.24 \\
\hline Mentors of white protégés compared with mentors of Asian protégés & $2.25(0.70-7.21)$ & 0.17 & $2.44(0.73-8.13)$ & 0.15 \\
\hline Black/Hispanic protégés compared with Asian protégés & $1.65(0.50-5.39)$ & 0.41 & $0.48(0.08-2.87)$ & 0.42 \\
\hline Mentors of Black/Hispanic protégés compared with mentors of Asian protégés & $0.74(0.21-2.60)$ & 0.64 & $1.20(0.35-4.10)$ & 0.77 \\
\hline Female protégés compared with male protégés & $1.00(0.39-2.60)$ & 0.99 & $0.43(0.11-1.62)$ & 0.21 \\
\hline Mentors of female protégés compared with mentors of male protégés & $0.90(0.35-2.33)$ & 0.83 & $0.63(0.14-2.79)$ & 0.54 \\
\hline
\end{tabular}

aThe odds ratios, confidence intervals, and $p$ values were obtained from a logistic regression model that included terms for intervention group, respondent (mentor, protégé), and the response to the item at baseline. The model was fitted using generalized estimating equations to account for the association between the mentor and protégé responses in the same dyad; the technique of alternating logistic regressions was used, with the associations between outcomes within the same dyad being modeled using a constant log odds ratio.

${ }^{b}$ White protégés include only non-Hispanic white protégés.

${ }^{\mathrm{c}} \mathrm{OR}$, odds ratio; $\mathrm{CI}$, confidence interval. 
TABLE 3. Effects of mentoring interventions on perceived amount and quality of time together as mentor-protégé dyada

\begin{tabular}{|c|c|c|c|c|}
\hline \multirow[b]{2}{*}{ Comparison } & \multicolumn{2}{|c|}{$\begin{array}{l}\text { Total amount of time with the } \\
\text { mentor/protégé is adequate }\end{array}$} & \multicolumn{2}{|c|}{$\begin{array}{l}\text { Quality of time with mentor/ } \\
\text { protégé is good or excellent }{ }^{b}\end{array}$} \\
\hline & OR $(95 \% \mathrm{CI})$ & $p$ value & OR $(95 \% \mathrm{CI})$ & $p$ value \\
\hline Mentor training compared with control condition & $1.67(0.78-3.61)$ & 0.19 & $1.91(0.86-4.27)$ & 0.11 \\
\hline Mentor-training main effect ${ }^{c}$ & $1.22(0.66-2.25)$ & 0.52 & $2.00(0.94-4.26)$ & 0.07 \\
\hline Peer mentoring compared with control condition & $1.65(0.69-3.92)$ & 0.26 & $2.02(0.87-4.68)$ & 0.10 \\
\hline Peer-mentoring main effect ${ }^{\mathrm{c}}$ & $1.20(0.65-2.23)$ & 0.55 & $2.12(1.00-4.48)$ & 0.05 \\
\hline Combined intervention compared with control condition & $1.47(0.63-3.42)$ & 0.37 & $4.24(1.26-14.30)$ & 0.02 \\
\hline
\end{tabular}

a The odds ratios, confidence intervals, and $p$ values were obtained from a logistic regression model that included terms for intervention group, respondent (mentor, protégé), and the response to the item at baseline. The model was fitted using generalized estimating equations to account for the association between the mentor and protégé responses in the same dyad; the technique of alternating logistic regressions was used, with the associations between outcomes within the same dyad being modeled using a constant log odds ratio.

bOR, odds ratio; CI, confidence interval.

'The mentor-training main effect refers to the comparison of those receiving mentor training (either alone or in combination with peer mentoring) and those not receiving mentor training (peer mentoring alone or control). The peer-mentoring main effect refers to the comparison of those receiving peer mentoring (either alone or in combination with mentor training) and those not receiving peer mentoring (mentor training alone or control).

vast majority of dyads discussed research, mentor training and peer mentoring were associated with greater likelihood of having discussed certain academic topics or professional/personal development topics. Furthermore, both interventions were associated with mentors' perceptions of having spent adequate time with their protégés. Among dyads, participation in the combined intervention group was associated with perceived better quality of time together compared with the control group.

We found differences between mentors and protégés in their perceptions of mentoring behaviors and experiences, as have others (Baldwin et al., 2012; Rosenthal et al., 2012; Martina et al., 2014; Dadiz and Guillet, 2015). Our mentors, regardless of group assignment, were more likely than protégés to report that they discussed certain topics on our list-especially those related to professional and personal development. It is possible that mentors were motivated to present themselves as effective mentors, thus unintentionally distorting their memory of the mentoring discussions, but it is also possible that protégés thought of discussions of developmental topics such as career plans and work-life balance as informal conversation rather than mentoring. Moreover, mentors who led discussions might have had better recall than protégés, who played a more passive role (Martina et al., 2014). Nonetheless, we recommend that mentors be deliberate and explicit in signaling to protégés that they are addressing specific topics. For example, a mentor might say to a protégé, "Next week, maybe we'll talk over your career plans. Think about what you need to learn, so we can cover your questions thoroughly."

Differences were few between mentor and protégé perceptions based on protégé race or ethnicity, except that mentors of Black or Hispanic protégés, compared with mentors of white protégés, were more likely to consider the amount of time spent together as inadequate. Mentors might have perceived that their Black and Hispanic protégés had greater needs, because minorities are less likely to be the beneficiaries of sponsorship and advocacy or to engage in the informal networking that so often facilitates career success (Dadiz and Guillet, 2015). Mentors of Black or Hispanic protégés may also have been conscious of reported racial and ethnic disparities in graduation rates (Jeffe et al., 2014) and faculty promotion rates (Fang et al., 2000; Nunez-Smith et al., 2012). Black and Hispanic protégés, on the other hand, who appeared to be somewhat more likely than white protégés to consider the amount of time spent together as adequate, may have been less willing (or less comfortable) than white protégés to seek help from their mentors for fear of being perceived as weak or less capable (Johnson, 2007; Beech et al., 2013).

There were few differences by gender in the topics discussed by the dyads. Not surprisingly, mentors with female protégés were more likely than those with male protégés to discuss work-life balance, and this was a common theme in the workshops. Several studies have shown that women with families devote more time to child-rearing and household duties than working men with families, leading to a greater need for women to manage their work duties efficiently (Shollen et al., 2009; Misra et al., 2012).

Our interventions may have facilitated greater protégé autonomy in directing interactions with their mentors toward personally relevant topics. Both peer mentoring and mentor training stressed individualization of mentor-protégé interactions; both approaches invited the protégé to be proactive and to take ownership over dyad interactions. Career planning and work-life balance are sensitive areas that protégés might be reluctant to discuss with their mentors in the absence of support from a peer-mentor group. Pololi et al. (2010) describe lack of social capital related to race, gender, and socioeconomic status as barriers to faculty career advancement. Peer-mentoring groups for underrepresented students (Martin et al., 2013), deaf students (Wilkens and Hehir, 2008), and women medical faculty (Pololi et al., 2010) have been tied to academic achievement and professional advancement. Our peer-mentor groups were designed to promote networks that facilitate acquisition of professional skills and a sense of engagement with the academic community, in part by providing a safe space to rehearse discussion of sensitive topics and to learn from others at the same career stage. Peer groups may also have benefited from workshops that addressed mentor-protégé communication and issues related to being in an underrepresented group. Similarly, the SDT-focused mentor training was designed to encourage mentors to consider protégés' needs for autonomously chosen professional and 


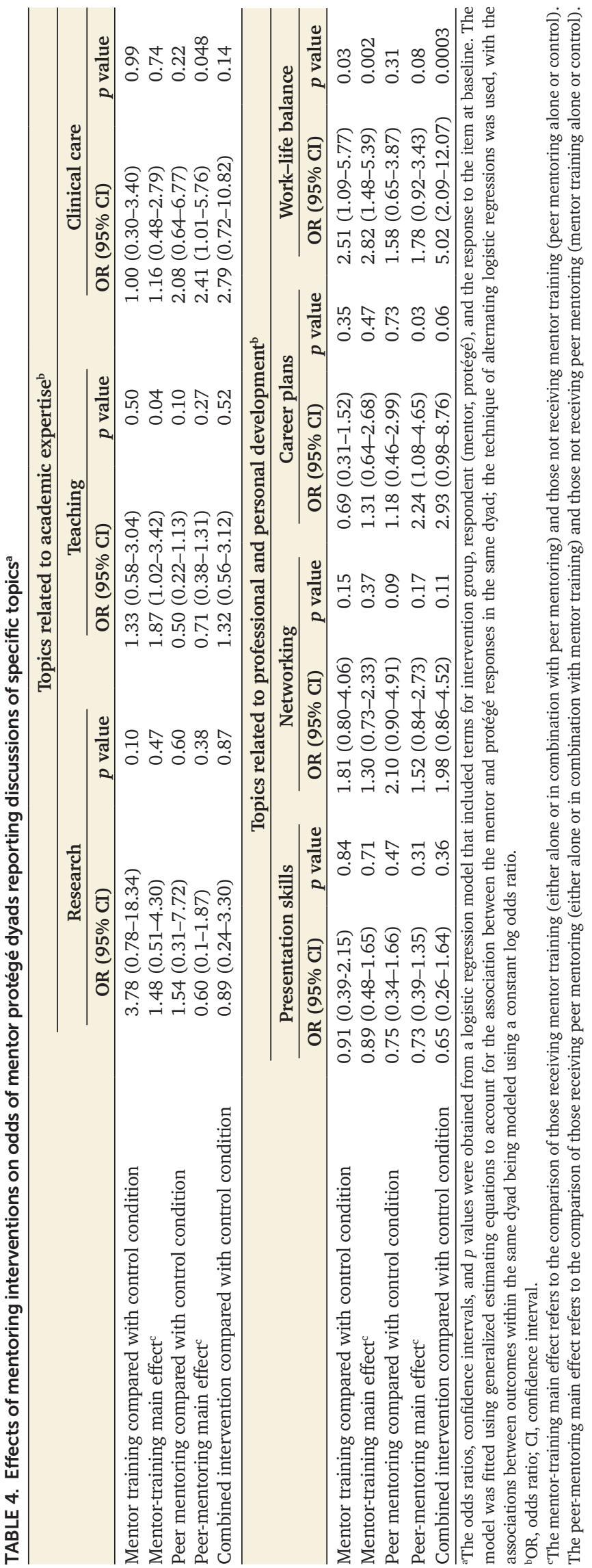

personal goals and their need to develop trusting mentoring relationships that would facilitate sensitive discussions, including support for desired work-life balance and protégé diversity.

Work-life balance is a topic with which mentors frequently struggle. As described by Fleming et al. (2013), "Helping protégés achieve work-life balance" was a topic that was near the bottom of competencies in a list of 26 mentoring skills ranked by mentors (self-assessing their skills) and protégés (assessing their mentors' skills). We found that work-life balance was discussed more frequently by dyads in the mentor-training and combined intervention groups than by those in the control group. Mentors who received the SDT-based training may have been more attuned to their protégés' needs to discuss work-life balance. In addition, the insights gained by mentors who discussed work-life balance with their protégés may have influenced their perception of having better-quality relationships with their protégés.

Dyads in the combined intervention group were also more likely than those in the control group to perceive that their time together was of high quality. They had the benefit of both the mentor training, which likely facilitated work-life balance discussions, and peer mentoring, which may have facilitated discussions about career planning. Also, communication skills that could facilitate a better mentor-protégé relationship were commonly discussed in the protégé peer workshops. Moreover, mentors in both the mentor-training and peer-mentoring groups were more likely than those in the control group to be satisfied with the amount of time spent with their protégés. Discussing a greater range of topics may have led them to see their time together as more productive, and therefore adequate in amount and higher in quality. A better experience for the mentors has the potential for long-term benefits by enhancing the willingness of mentors to work with other protégés (Feldman et al., 2012). This potential benefit is important, because mentoring is often an uncompensated activity with variable departmental support that busy faculty may be reluctant to undertake (Rosenthal and Black, 2006; Moseley and Davies, 2008; Kashiwagi et al., 2013).

\section{Strengths and Limitations}

Our randomized controlled trial study design and focus on underrepresented scholars are major strengths. Inclusion of participants representing different academic levels in multiple institutions makes it more likely that the results are generalizable. We focused on mentoring of underrepresented protégés because this is an essential requirement for successful career development in academia. We studied two approaches to helping mentors and protégés with common issues faced by protégés related to being underrepresented in their disciplines, which can provide a basis for further research into tools that translate across scientific and professional fields. These novel mentoring interventions are based on a solid theoretical foundation of SDT and social capital theory, theories that are particularly relevant to the career development needs of underrepresented protégés. Given that our topic was the quality of mentoring of these protégés under different mentoring interventions, we focused on mentors' and protégés' perceptions of the quality of their interactions in the context of the time they spent together. Time spent together is the most important factor in a mentor-protégé relationship (Johnson, 2007). Our 
findings suggest that mentoring interventions that are consistent with SDT and social capital theory in fact may enhance the mentoring relationships of these dyads.

Our study is limited in that we have not yet measured the impact of our traditional and peer-mentoring interventions on protégés' career choices and academic productivity. We are currently collecting data on these outcomes. The heterogeneity of the academic disciplines and professional levels included in this study makes such a follow-up study especially challenging. Current efforts are underway to explore protégé outcomes beyond 1 year, as well as to evaluate the potential of refined versions of our interventions to meet targeted needs of specific disciplines.

Another limitation is our inability to discuss the specific content of dyad discussions or whether protégés or mentors valued certain topics more than others. Furthermore, our study did not document whether protégés may have had multiple mentors/ advisors; these could have provided additional support in areas not addressed through the single mentoring relationship that we studied. Another limitation is that our explanations of our findings, although based on previous literature, cannot be definitive. Further research is needed to confirm our initial findings and their interpretation.

Finally, the findings of this secondary analysis need to be interpreted with appropriate caution given the multiple outcome variables examined and the multiple group comparisons performed, which may have increased the probability of false-positive findings (type I error). The results may be best viewed as hypothesis-generating data. In particular, many of the negative subgroup findings (e.g., lack of differences among gender groups and races/ethnicities) are inconclusive, given the relatively small subgroup sample sizes.

\section{CONCLUSIONS AND SIGNIFICANCE}

Our findings suggest the potential benefits of a structured professional development program based on SDT principles and social capital theory to achieve high-quality mentoring. Consistent with SDT, mentor training appears to have fostered a wider choice of academic discussion topics, and the trust built through enhanced relatedness may have led to discussion of more personal topics such as work-life balance. Consistent with social capital theory, protégés in peer-mentoring groups developed new informal networks from which to learn about both academic topics and topics related to personal and professional development. These discussions likely contributed to the perceptions of protégés' in the combined intervention group of overall better quality of time for mentor-protégé dyads. Overall, participants in any of the three interventions appeared to have a broader mentoring experience than that offered by usual mentoring practice, as indicated by the greater likelihood of discussion of topics that are important for success in academia.

The potential benefits for protégés in this professional development program include a greater knowledge of institutional resources and an enhanced sense of professional identity. Mentors may also benefit by enjoying richer relationships with protégés and feeling more successful in their mentoring roles.

Our study focused on underrepresented early-career scholars, a group that has been understudied and that may especially benefit from high-quality mentoring. Our findings point to the potential value of both mentor-training and peer group-mentoring interventions to enhance the breadth and diversity of discussions by mentor-protégé dyads and the quality of their time together. The topics discussed are known to be highly relevant to career growth and satisfaction, and are especially critical for the development of underrepresented scholars in their early years in academia. We believe that our theoretical approach, study design, and methodology are well aligned. Our findings suggest that mentoring interventions that are consistent with SDT and social capital theory may enhance the mentoring relationships of these dyads. Future research should attempt to examine the sustainability of these interventions and deepen our understanding of mentor-protégé relationships.

\section{ACKNOWLEDGMENTS}

We thank Thomas A. Pearson, MD, PhD, and Steven Dewhurst, $\mathrm{PhD}$, for their advice about study design and execution. We are very grateful for the outstanding editorial assistance of Constance Baldwin, $\mathrm{PhD}$. We appreciate invaluable work done by our study coordinators, Caitlin Powalski, MPH, Farzia Sayidine Kaufman, MS, and Natalia Andrievskaia, MS, who provided ideas, logistical support, and quality control. We also thank all participating academic medical centers, schools, and research institutions: D'Youville College; Le Moyne College; Rochester Institute of Technology; Roswell Park Cancer Institute; SUNY Buffalo State College; SUNY College of Environmental Science and Forestry; SUNY Geneseo; SUNY Upstate Medical University; Syracuse University; University at Buffalo, SUNY; and University of Rochester. This study was supported by grant 1DP4GM096850-01 from the National Institute of General Medical Sciences and grant 1 UL1RR024160-1 from the National Center for Advancing Translational Sciences.

\section{REFERENCES}

Abedin, Z., Biskup, E., Silet, K., Garbutt, J. M., Kroenke, K., Feldman, M. D., .. Pincus, H. A. (2012). Deriving competencies for mentors of clinical and translational scholars. Clinical and Translational Science, 5(3), 273-280. doi: http://dx.doi.org/10.1111/j.1752-8062.2011.00366.x

Baard, P. P., Deci, E. L., \& Ryan, R. M. (2004). Intrinsic need satisfaction: A motivational basis of performance and well-being in two work settings. Journal of Applied Social Psychology, 34, 2045-2068.

Baldwin, C. D., Craig, M. S., Garfunkel, L. C., Harris, J. P., Shone, L. P., Biondi, E., ... Varade, W. S. (2012). Autonomy-supportive medical education: Let the force be within you! Academic Medicine, 87(11), 1468-1469. doi: http://dx.doi.org/10.1097/ACM.0b013e31826cdc3f

Beech, B. M., Calles-Escandon, J., Hairston, K. G., Langdon, S. E., LathamSadler, B. A., ... Bell, R. A. (2013). Mentoring programs for underrepresented minority faculty in academic medical centers: A systematic review of the literature. Academic Medicine, 88(4), 541-549.

Bourdieu, P. (1986). The forms of capital. In Richardson, J. G. (Ed.), Handbook of theory and research for the sociology of education (pp. 241-258) New York: Greenwood.

Bourdieu, P. (1998). Practical reason: On the theory of action. Stanford, CA Stanford University Press.

Bourdieu, P., \& Wacquant, L. J. (1992). An invitation to reflexive sociology Chicago: University of Chicago Press. 
Carey, V., Zeger, S. L., \& Diggle, P. (1993). Modelling multivariate binary data with alternating logistic regressions. Biometrika, 80(3), 517-526. doi:10.1093/biomet/80.3.517

Carnes, M., Devine, P. G., Baier Manwell, L., Byars-Winston, A., Fine, E., Ford, C. E., ... Sheridan, J. (2015). The effect of an intervention to break the gender bias habit for faculty at one institution: A cluster randomized, controlled trial. Academic Medicine, 90(2), 221-230. doi:10.1097/ acm.0000000000000552

Carr, P. L., Szalacha, L., Barnett, R., Caswell, C., \& Inui, T. (2003). A "ton of feathers": Gender discrimination in academic medical careers and how to manage it. Journal of Women's Health, 12(10), 1009-1018. doi:10.1089/154099903322643938

Cora-Bramble, D., Zhang, K., \& Castillo-Page, L. (2010). Minority faculty members' resilience and academic productivity: Are they related? Academic Medicine, 85(9), 1492-1498. doi: http://dx.doi.org/10.1097/ ACM.0b013e3181df12a9

Dadiz, R., \& Guillet, R. (2015). Educational perspectives: Mentors, protégés, and the mentoring relationship. NeoReviews, 16(2), e62-e68. doi:10.1542/neo.16-2-e62

DeCastro, R. M. S., Sambuco, D. M., Ubel, P. A. M. D., Stewart, A. P., \& Jagsi, R. M. D. D. (2013). Mentor networks in academic medicine: Moving beyond a dyadic conception of mentoring for junior faculty researchers. Academic Medicine, 88(4), 488-496.

Deci, E. L., Olfasen, A. H., \& Ryan, R. M. (2017). Self-determination theory in work organizations: The state of a science. Annual Review of Organizational Psychology and Organizational Behavior, 4, 19-43.

Deci, E. L., \& Ryan, R. M. (2000). The "what" and "why" of goal pursuits: Human needs and the self-determination of behavior. Psychological Inquiry, 11(4), 227-268.

Deci, E. L., \& Ryan, R. M. (2014). The importance of universal psychological needs for understanding motivation in the workplace. In Gagne, M. (Ed.), The Oxford handbook of work engagement, motivation, and self-determination theory (pp. 13-32). New York: Oxford University Press.

Diggle, P. J., Heagerty, P. J., Liang, K.-Y., \& Zeger, S. L. (2002). Analysis of longitudinal data (2nd ed.). Oxford, UK: Oxford University Press.

Fang, D., Moy, E., Colburn, L., \& Hurley, J. (2000). Racial and ethnic disparities in faculty promotion in academic medicine. Journal of the American Medical Association, 284(9), 1085-1092.

Faupel-Badger, J. M., Raue, K., Nelson, D. E., \& Tsakraklides, S. (2015). Alumni perspectives on career preparation during a postdoctoral training program: A qualitative study. CBE-Life Sciences Education, 14(1), ar1. doi: http://dx.doi.org/10.1187/cbe.14-06-0102

Feldman, M. D., Steinauer, J. E., Khalili, M., Huang, L., Kahn, J. S., Lee, K. A., Brown, J. S. (2012). A mentor development program for clinical translational science faculty leads to sustained, improved confidence in mentoring skills. Clinical and Translational Science, 5(4), 362-367. doi: http:// dx.doi.org/10.1111/j.1752-8062.2012.00419.x

Fleming, M., House, S., Hanson, V. S., Yu, L., Garbutt, J., McGee, R., ... Rubio, D. M. (2013). The mentoring competency assessment: Validation of a new instrument to evaluate skills of research mentors. Academic Medicine, 88(7), 1002-1008. doi: 1010.1097/ACM.1000b1013e318295e318298

Gonzales-Figueroa, E., \& Young, A. M. (2005). Ethnic identity and mentoring among Latinas in professional roles. Cultural Diversity \& Ethnic Minority Psychology, 11(3), 213-226.

Huskins, W. C., Silet, K., Weber-Main, A. M., Begg, M. D., Fowler, V. G. Jr., Hamilton, J., \& Fleming, M. (2011). Identifying and aligning expectations in a mentoring relationship. Clinical and Translational Science, 4(6), 439447. doi:10.1111/j.1752-8062.2011.00356.x

Isaac, C., Kaatz, A., Lee, B., \& Carnes, M. (2012). An educational intervention designed to increase women's leadership self-efficacy. CBE-Life Sciences Education, 11(3), 307-322. doi:10.1187/cbe.12-02-0022

Jeffe, D. B., Andriole, D. A., Wathington, H. D., \& Tai, R. H. (2014). Educational outcomes for students enrolled in MD-PHD programs at medical school matriculation, 1995-2000: A national cohort study. Academic Medicine 89(1), 84-93. doi: http://dx.doi.org/10.1097/ACM.0000000000000071

Johnson, K. S., Hastings, S. N., Purser, J. L., \& Whitson, H. E. (2011). The junior faculty laboratory: An innovative model of peer mentoring. Academic Medicine, 86(12), 1577-1582.
Johnson, M. O., Subak, L. L., Brown, J. S., Lee, K. A., \& Feldman, M. D. (2010) An innovative program to train health sciences researchers to be effective clinical and translational research mentors. Academic Medicine 85(3), 484-489. doi: http://dx.doi.org/10.1097/ACM.0b013e3181cccd12

Johnson, W. B. (2007). On being a mentor-A guide for higher education faculty. Mahwah, NJ: Erlbaum.

Kaatz, A., \& Carnes, M. (2014). Stuck in the out-group: Jennifer can't grow up, Jane's invisible, and Janet's over the hill. Journal of Women's Health 23(6), 481-484. doi:10.1089/jwh.2014.4766

Kashiwagi, D. T., Varkey, P., \& Cook, D. A. (2013). Mentoring programs for physicians in academic medicine: A systematic review. Academic Medicine, 88(7), 1029-1037. doi:10.1097/ACM.0b013e318294f368

Kram, K. E., \& Ragins, B. R. (Eds.). (2007). The handbook of mentoring at work: Theory, research, and practice. Los Angeles: Sage.

Lewis, V., Martina, C. A., McDermott, M. P., Trief, P. M., Goodman, S. R., Morse, G. D., ... Ryan, R. M. (2016). A randomized controlled trial of mentoring interventions for underrepresented minorities. Academic Medicine, 91(7), 994-1001. doi:10.1097/acm.0000000000001056

Lin, N. (1999a). Building a network theory of social capital. Connections, $22(1), 28-51$

Lin, N. (1999b). Social networks and status attainment. Annual Review of Sociology, 25, 467-487.

Martin, J. P., Simmons, D. R., \& Yu, S. L. (2013). The role of social capital in the experiences of Hispanic women engineering majors. Journal of Engineering Education, 102(2), 227-243. doi:10.1002/jee.20010

Martina, C. A., Mutrie, A., Ward, D., \& Lewis, V. (2014). A sustainable course in research mentoring. Clinical and Translational Science, 7(5), 413-419. doi:10.1111/cts.12176

Millette, V., \& Gagné, M. (2008). Designing volunteers' tasks to maximize motivation, satisfaction and performance: The impact of job characteristics on volunteer engagement. Motivation and Emotion, 32(1), 11-22. doi: http://dx.doi.org/10.1007/s11031-007-9079-4

Misra, J., Lundquist, J. H., \& Templer, A. (2012). Gender, work time, and care responsibilities among faculty. Sociological Forum, 27(2), 300-323.

Moseley, L. G., \& Davies, M. (2008). What do mentors find difficult? Journal of Clinical Nursing, 17(12), 1627-1634.

Nunez-Smith, M., Ciarleglio, M. M., Sandoval-Schaefer, T., Elumn, J., CastilloPage, L., Peduzzi, P., \& Bradley, E. H. (2012). Institutional variation in the promotion of racial/ethnic minority faculty at us medical schools. American Journal of Public Health, 102(5), 852-858

Pfund, C., House, S., Spencer, K., Asquith, P., Carney, P., Masters, K. S., .. Fleming, M. (2013). A research mentor training curriculum for clinical and translational researchers. Clinical and Translational Science, 6(1), 26-33. doi:10.1111/cts.12009

Pfund, C., House, S. C., Asquith, P., Fleming, M. F., Buhr, K. A., Burnham, E. L., Sorkness, C. A. (2014). Training mentors of clinical and translational research scholars: A randomized controlled trial. Academic Medicine, 89(5), 774-782. doi:10.1097/acm.0000000000000218

Pololi, L., Cooper, L. A., \& Carr, P. (2010). Race, disadvantage and faculty experiences in academic medicine. Journal of General Internal Medicine, 25(12), 1363-1369. doi: http://dx.doi.org/10.1007/s11606-010-1478-7

Pololi, L., \& Knight, S. (2005). Mentoring faculty in academic medicine. A new paradigm? Journal of General Internal Medicine, 20(9), 866-870. doi: http://dx.doi.org/10.1111/j.1525-1497.2005.05007.x

Pololi, L. H., Knight, S. M., Dennis, K., \& Frankel, R. M. (2002). Helping medical school faculty realize their dreams: An innovative, collaborative mentoring program. Academic Medicine, 77(5), 377-384.

Pololi, L. H., Krupat, E., Schnell, E. R., \& Kern, D. E. (2013). Preparing culture change agents for academic medicine in a multi-institutional consortium: The C-change learning action network. Journal of Continuing Education in the Health Professions, 33(4), 244-257. doi: http://dx.doi org/10.1002/chp.21189

Price, E. G., Powe, N. R., Kern, D. E., Golden, S. H., Wand, G. S., \& Cooper, L. A. (2009). Improving the diversity climate in academic medicine: Faculty perceptions as a catalyst for institutional change. Academic Medicine, 84(1), 95-105. doi: http://dx.doi.org/10.1097/ACM.0b013e3181900f29

Prunuske, A. J., Wilson, J., Walls, M., \& Clarke, B. (2013). Experiences of mentors training underrepresented undergraduates in the research laboratory. 
CBE-Life Sciences Education, 12(3), 403-409. doi: http://dx.doi.org/ 10.1187/cbe.13-02-0043

Rosenthal, S. L., Ebel, S. C., Omondi, E. A., \& Hum, R. S. (2012). Do mentors know who they are mentoring? Journal of Pediatrics, 161(5), 773-774. doi: http://dx.doi.org/10.1016/j.jpeds.2012.07.059

Rosenthal, S. L. P., \& Black, M. M. P. (2006). Commentary: Mentoring-Benchmarks for work performance. Journal of Pediatric Psychology, 31(6), 643-646.

Ryan, R. M., \& Deci, E. L. (2000). Self-determination theory and the facilitation of intrinsic motivation, social development, and well-being. American Psychologist, 55(1), 68-78.

Shollen, S. L., Bland, C. J., Finstad, D. A., \& Taylor, A. L. (2009). Organizational climate and family life: How these factors affect the status of women faculty at one medical school. Academic Medicine, 84(1), 87-94. doi: http://dx.doi.org/10.1097/ACM.0b013e3181900edf

Silet, K. A., Asquith, P., \& Fleming, M. F. (2010). Survey of mentoring programs for kl2 scholars. Clinical and Translational Science, 3(6), 299-304.
Stewart, T. L., Latu, I. M., Branscombe, N. R., Phillips, N. L., \& Denney, H. (2012). White privilege awareness and efficacy to reduce racial inequality improve white Americans' attitudes toward African Americans. Journal of Social Issues, 68(1), 11-27. doi: http://dx.doi.org/10.1111/j.1540-4560 2012.01733.x

Sue, D. W. (2008). Multicultural organizational consultation: A social justice perspective. Consulting Psychology Journal: Practice and Research, 60(2), 157-169. doi: http://dx.doi.org/10.1037/0736-9735.60.2.157

Sue, D. W. (2011). The challenge of white dialectics: Making the "invisible" visible. Counseling Psychologist, 39(3), 415-422. doi: http://dx.doi org/10.1177/0011000010390702

Turner, C. S. V., Gonzalez, J. C., \& Wood, L. J. (2008). Faculty of color in academe: What 20 years of literature tells us. Journal of Diversity in Higher Education, 1(3), 139-168.

Wilkens, C. P., \& Hehir, T. P. (2008). Deaf education and bridging social capital: A theoretical approach. American Annals of the Deaf, 153(3), 275284 